\title{
Two new species of Sepsidae (Diptera) from Vietnam
}

\section{Ава новых вида мух-муравьевидок (Diptera: Sepsidae) из Вьетнама}

\author{
A.L. Ozerov ${ }^{1}$, M.G. Krivosheina ${ }^{2}$ \\ А. $\Lambda$. Озеров ${ }^{1}$, М.Г. Кривошеина ${ }^{2}$
}

\begin{abstract}
${ }^{1}$ Zoological Museum, Moscow Lomonosov State University, Bol'shaya Nikitskaya 6, Moscow 125009, Russia. E-mail: ozerov2455@rambler.ru

1Зоологический музей, Московский государственный университет им. М.В. Ломоносова, Большая Никитская ул., 6, Москва 125009 , Россия.

${ }^{2}$ A.N. Severtzov Institute of Ecology and Evolution, Russian Academy of Sciences, 119071 Moscow, Russia, e-mail: dipteramarina@rambler.ru

${ }^{2}$ Институт проблем экологии и эволюции им. А.Н.Северцова РАН, Ленинский проспект, 33, Москва 119071, Россия.
\end{abstract}

KEYWORDS: Diptera, Sepsidae, Vietnam, new species.

КЛЮЧЕВЫЕ СЛОВА: Diptera, Sepsidae, Вьетнам, новые виды.

ABSTRACT. Two new to science species of Sepsidae from Vietnam are described: Dicranosepsis kaloedka, sp.n. and Sepsis sapaensis, sp.n. The specimens were collected on water buffalo and dog dung.

РЕЗЮМЕ. Описаны два новых для науки вида мух-муравьевидок (Sepsidae) из Вьетнама: Dicranosepsis kaloedka, sp.n. и Sepsis sapaensis, sp.n. Экземпляры были собраны на экскрементах буйвола и собаки.

\section{Introduction}

Sepsidae are small to moderately sized yellow or black flies, many of which superficially resemble winged ants. Larvae breed in various decaying organic matter (decaying fungi, animal or human dung and carcasses). Adults usually concentrate near or upon these substrata.

Sepsidae are known from all continents, except Antarctica. More than 330 species are known world wide, of which about 100 are recorded from the Oriental Region. 6 genera and 28 species were registered in Vietnam before [Ozerov 2005; Iwasa, 2008; Iwasa \& Thinh, 2008; Ang \& Meier, 2010].

A recent collecting trip to Vietnam yielded 18 species of Sepsidae, two of them are new to science. At the present time M. Iwasa (Obihiro University of Agriculture and Veterinary Medicine, Japan) is preraring the work with review of Vietnam Sepsidae, but these species remain unknown for him (pers. comm.). The descriptions of these species are given below.

All species were collected between 28 March - 7 April 2011 from Northern Vietnam: Sa Pa Valley and mountains in Hoang Lien National Park. All type-spe- cimens are kept in the Zoological Museum, Moscow State University (ZMUM).

\section{Descriptions of new species}

Dicranosepsis kaloedka, sp.n. Figs 1-3.

TYPE MATERIAL. Holotype $\sigma^{\prime}$, VIETNAM: Lao Cai Province, $\mathrm{Sa} \mathrm{Pa}, 1525 \mathrm{~m}\left(22.341421^{\circ} \mathrm{N}, 103.851068^{\circ} \mathrm{E}\right)$, on water buffalo (Bubalus bubalis) dung, 30.III. 2011, coll. A. Ozerov \& A. Medvedev (ZMUM). Holotype glued on carton card, in exellent condition.

Paratypes: $4 \sigma^{\top} \sigma^{7}$, with same label as holotype; $2 \sigma^{7} \sigma^{7}$, Lai Chau Province, Hoang Lien National Park, $\left(22.348191^{\circ} \mathrm{N}\right.$, $\left.103.769786^{\circ} \mathrm{E}\right), 1849 \mathrm{~m}$, on human faeces, 2.IV.2011, coll. A. Ozerov \& A. Medvedev; $2 \Im^{\top} \sigma^{7}$, Lai Chau Province, Hoang Lien National Park, $\left(22.348542^{\circ} \mathrm{N}, 103.770024^{\circ} \mathrm{E}\right), 1806 \mathrm{~m}$, on human faeces, 7.IV.2011, coll. A. Ozerov \& A. Medvedev.

DESCRIPTION. Length of body: 2.9-3.3 $\mathrm{mm}$. Length of wing: $2.5-2.8 \mathrm{~mm}$.

Head in lateral view slightly flattened dorsoventrally. Eye roundish. Frons black, shining. Face and gena dark brown or blackish, with whitish microtrichia. Postcranium black, microtrichose. Antenna blackish, postpedicel yellowish internally near base. Postpedicel in profile oval, slightly longer than wide. 1 ocellar, 1 postocellar, 1 inner vertical, 1 outer vertical setae present; $2-3$ vibrissae. Lateral occipital sclerite with several setulae.

Thorax black. Scutum microtrichose, usually with shining spot above notopleura. Proepisternum densely microtrichose in lower part and shining or subshining in upper part. Proepimeron shining in upper part and densely microtrichose in lower part. Anepisternum shining. Katepisternum shining, but along upper and posterior margins densely microtrichose. Anepimeron shining in anerior half and densely microtrichose in poste- 

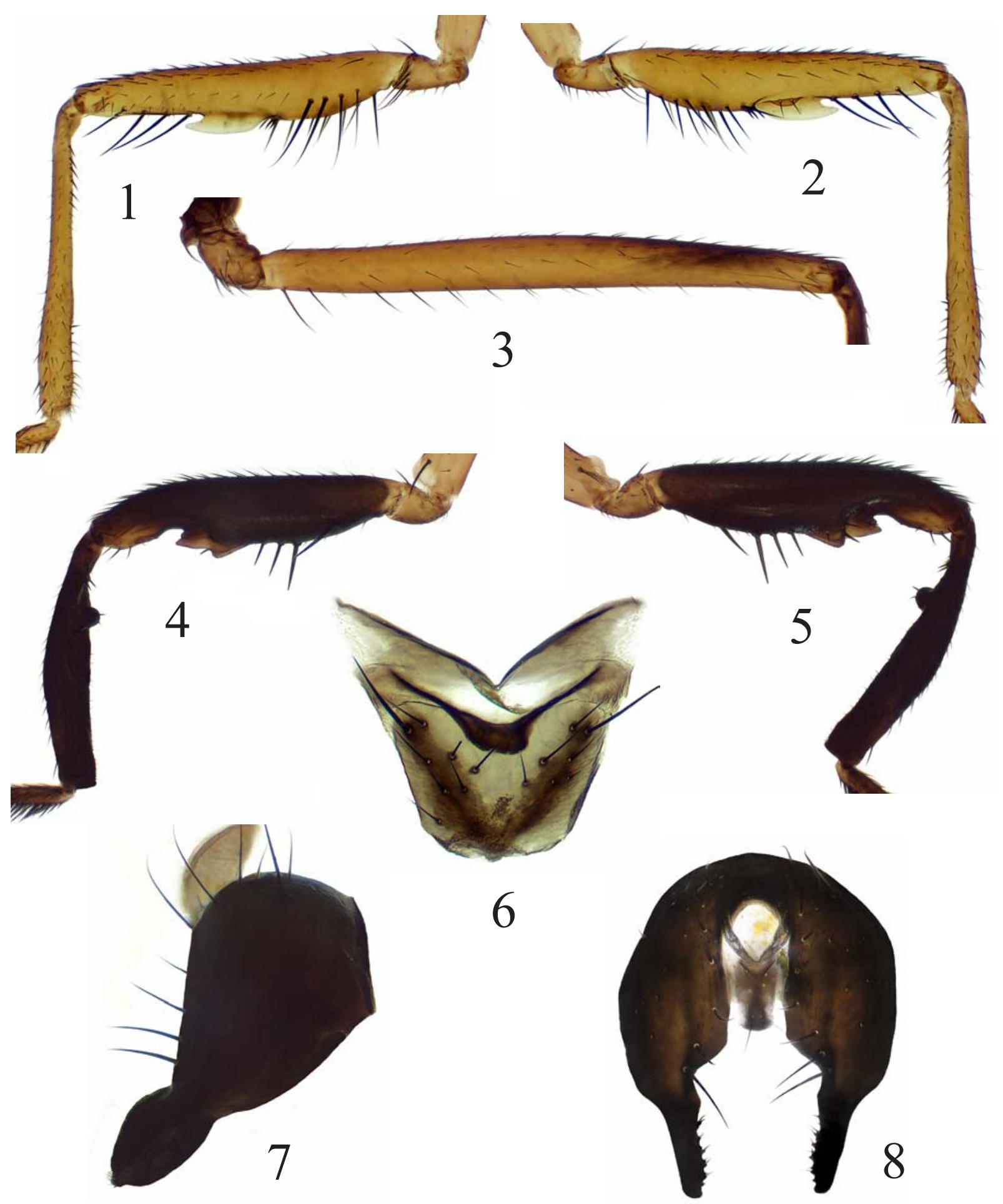

Figs 1-8. Dicranosepsis kaloedka, sp.n. (1-3) and Sepsis sapaensis, sp.n. (4-8), paratype $\sigma^{7}: 1,4$ - foreleg (right), anterior view; 2 , 5 - same, posterior view; 3 - hindfemur (right), posterior view; 6 - abdominal sternites 4 and $5 ; 7$ - epandrium and surstylus, lateral view; 8 - epandrium and surstyli, dorsal view.

Рис. 1-8. Dicranosepsis kaloedka, sp.n. (1-3) и Sepsis sapaensis, sp.n. (4-8), паратип О’: 1, 4- передняя правая нога, спереди; 2, 5 - тоже, сзади; 3 - бедро задней правой ноги, сзади; 6 - стерниты 4 и 5 брюшка; 7 - эпандрий и сурстиль, сбоку; 8 эпандрий и сурстили, сверху. 
rior half; pleural wing process with grey microtrichia. Katepimeron, meron, metepisternum and metepimeron completely densely microtrichose. Katatergite and anatergite with dense grey microtrichia. Mediotergite shining under scutellum. Scutum with 1 postpronotal, 2 notopleural, 1 supra-alar, 1 postalar, and 2 postsutural dorsocentral setae; 1 anepisternal (near posterior margin) seta present. Scutellum with pair of well-developed apical setae and pair of basal setulae. Metepimeral (=postcoxal) bridge present.

Legs mostly yellow, but midfemur and hindfemur in apical third anterodorsally, midtibia and hindtibia in basal third, and 4-5 tarsomeres of all legs blackish. Coxa of foreleg simple, with 1 apical anterodorsal seta. Foreleg as in Figs 1, 2. Fore trochanter simple, with 2 3 setae inside apically. Forefemur with 3-4 av near base and row of $p v$ setae in basal half and 3-4 $p v$ in apical third. Midcoxa with a row of short hairs in upper half. Midfemur with row of $a$ setulae. Midtibia with 1 $a v$ in apical third and apical $a v$. Hindfemur with row of $p v$ setulae, basal of which long (Fig. 3). Hindtibia without striking setae, with hardly visible osmeteriumlike area in apical half anterodorsally.

Wing normal, longer than abdomen, with mode-rately developed anal lobe; clear, without blackish spots or darkening; veins blackish. Cells $b m$ and $b r$ separate. Alula entirely covered with microtrichia, its width approximately 1.5 times as width of cell $\mathrm{bm}$. Calypteres, including margins, brownish. Margin of upper calypter with hairs, margin of lower calypter without hairs. Halter yellowish.

Abdomen shining, strongly constricted after syntergite $1+2$. Syntergite $1+2$ and rest of tergites without striking setae. Surstyli symmetrical, typical for species of genus Dicranosepsis.

Female unknown.

DIAGNOSIS. The new species can be distinguished using the key to species of Dicranosepsis in Iwasa \& Thinh [2008], supplemented by the following couplets.

23. Proepisternum shining in upper part ....................... 23' - Proepisternum completely pruinose .............................. 24

23 '. Forefemur without strong anteroventral flattened protuberance, without $p v$ setae [Ozerov, 1997: 145, Figs 41, 42]. Hindfemur without row of $p v$ setulae

D. iwasai Ozerov

- Forefemur with strong anteroventral flattened protuberance, with row of $p v$ setae in basal half and 3-4 $p v$ in apical third (Figs 1,2). Hindfemur with row of $p v$ setulae, basal of which long (Fig. 3) ................................ 24'

24'. Trochanter of fore leg without setae inside apically. Forefemur with 1 strong $a v$ basally ..... D. stabilis Iwasa

- Trochanter of fore leg with 2-3 setae inside apically (Fig. 1). Forefemur with 3-4av near base (Fig. 1) ... D. kaloedka, sp.n.

\section{Sepsis sapaensis, sp.n.}

Figs 4-8.

TYPE MATERIAL. Holotype $\sigma^{7}$, VIETNAM: Lao Cai Province, $\mathrm{Sa} \mathrm{Pa}, 1525 \mathrm{~m}\left(22.341421^{\circ} \mathrm{N}, 103.851068^{\circ} \mathrm{E}\right)$, on dog dung,
4.IV.2011, coll. A. Ozerov \& A. Medvedev (ZMUM). Holotype glued on carton card, in exellent condition.

Paratypes: $9 \sigma^{7} \sigma^{7}, 4$, + , with same label as holotype; $9 \sigma^{7} \sigma^{7}$, Lao Cai Province, $\mathrm{Sa} \mathrm{Pa}, 1525 \mathrm{~m}\left(22.341421^{\circ} \mathrm{N}, 103.851068^{\circ} \mathrm{E}\right)$, on dog dung, 29-30.III., 1 and 6.IV.2011, coll. A. Ozerov \& A. Medvedev.

DESCRIPTION. Length of body: 2.4-3.9 mm. Length of wing: $2.1-3.3 \mathrm{~mm}$.

Head in lateral view slightly flattened dorsoventrally. Eye roundish. Frons black, shining. Face and gena brown, with whitish microtrichia. Postcranium black, with whitish microtrichia. Scapus and pedicel blackish, postpedicel brown. Height of gena below eye approximately $1 / 7$ times as long as vertical diameter of eye. Postpedicel in profile long-oval, approximately 1.5 times longer than wide. 1 ocellar, 1 postocellar, 1 inner vertical, 1 outer vertical setae present; $2-3$ vibrissae. Lateral occipital sclerite with several setulae.

Thorax black. Scutum and proepisternum microtrichose. Proepimeron and anepisternum subshining. Katepisternum completely densely microtrichose. Anepimeron shining; pleural wing process with grey microtrichia. Katepimeron, meron and metepisternum completely greyish microtrichose. Metepimeron shining. Katatergite and anatergite with grey microtrichia. Mediotergite shining. Scutum with 1 postpronotal, 2 notopleural, 1 supra-alar, 1 postalar, and 1 postsutural dorsocentral setae; 1 anepisternal (near posterior margin) seta present. Scutellum with pair of well-developed apical setae and pair of basal setulae. Metepimeral (=postcoxal) bridge absent.

Legs. Forecoxa yellow. Forefemur and foretibia black. Mid- and hindfemora mostly yellow, but black in posterior third and at middle dorsoposteriorly. Midand hindtibiae and all tarsi blackish. Coxa of foreleg simple, with 1 apical anterodorsal seta. Foreleg as in Figs 4, 5. Midcoxa with a row of short hairs in upper half. Midfemur with $1 a$ at middle. Midtibia with 1-2 $a v$ and $1-2 p$ in apical third, and apical $a v, p v$, and $a d$. Hindfemur without striking setae. Hindtibia with a hardly visible osmeterium-like area near middle anterodorsally, with $1 a$ in apical half, and with 1 preapical $d$.

Wing normal, longer than abdomen, with well-developed anal lobe; clear, with black spot at apex of $\mathrm{R}_{2+3}$; veins blackish. Cells $b m$ and $b r$ separate. Alula entirely covered with microtrichia, its width approximately 2.5 times as width of cell $\mathrm{bm}$. Calypteres, including margins, black. Margin of upper calypter with hairs, margin of lower calypter without hairs. Halter whitish.

Abdomen shining, moderately constricted after syntergite $1+2$. Syntergite $1+2$ at sides with several thin setae. Tergite 4 with 2 marginal setae. Sternites 4 and 5 as in Fig. 6. Surstyli symmetrical, fused to epandrium, wide (Fig. 7, 8).

Female resembles male. Femur and tibia of foreleg simple.

DIAGNOSIS. This new species resembles $S$. latiforceps Duda, 1926 by structure of surstyli, and $S$. lindneri Hennig, 1949 by structure of foreleg, but combination of wide surstylus and flattened foretibia is inique for $S$. sapaensis. 
ACKNOWLEDGEMENTS. The authors would like to thank Dr. Nikita Vikhrev (Moscow, Russia) for the financial support of the collection trip to North Vietnam. We express our sincere thanks to Dr. Mitsuhiro Iwasa (Obihiro, Japan) for collaboration and valuable information.

\section{References}

Ang Y., Meier R. 2010. Five additions to the list of Sepsidae (Diptera) for Vietnam: Perochaeta cuirassa sp. n., Perochaeta lobo sp. n., Sepsis spura sp. n., Sepsis sepsi Ozerov, 2003 and Sepsis monostigma Thompson, 1869 // ZooKeys. Vol.70. P. $41-56$.
Iwasa M. 2008. Revisional notes on the genus Toxopoda Macquart (Diptera, Sepsidae) in the Oriental and Australasian regions // Entomological Science. Vol.11. P.449-463.

Iwasa M., Thinh T.H. 2008. Six new species of the genus Dicranosepsis Duda (Diptera, Sepsidae) from Vietnam, with a revised key to the species // Entomological Science. Vol.11. P.65-73.

Iwasa M., Zuska J., Ozerov A.L. 1991. The Sepsidae from Bangladesh, with description of a new species (Diptera) // Japanese Journal of Sanitary Zoology. Vol.42. No.3. P.229-234.

Ozerov A.L. 1997. A revision of the genus Dicranosepsis Duda (Diptera, Sepsidae) // Russian Entomological Journal. Vol.5. No.1-4 (for 1996). P.135-161.

Ozerov A.L. 2005. World catalogue of the family Sepsidae (Insecta: Diptera) // Zoologicheskie Issledovania. No.8. 74 p. 